\title{
8. Policy adaptation to address early job insecurity in Europe
}

\section{Ondřej Hora, Markéta Horáková and Tomáš Sirovátka}

\section{INTRODUCTION}

This chapter, based on the theoretical background provided in Hora et al. (Chapter 7 this volume), identifies general patterns in four policy areas, as well as trends during the crisis and post-crisis period (2007-13). The question in focus is how different countries responded to the challenges of early job insecurity. We examine whether the policy responses represented stronger or weaker reactions: first-order policy change (innovations in the use of existing measures); second-order policy change (new measures implemented); or third-order policy change (new policy paradigm), as distinguished by Hall (1993). Finally, we assess the extent to which the responses were appropriate to the problems facing the countries at the time. We adopt an employment-regime approach to explain the logic of different policy packages and the differences in policy coordination in the countries under study, which are representatives of the five different employment regimes described in Hora et al. (Chapter 7 this volume): Norway (inclusive regime), Germany and Switzerland (employmentcentred regime), United Kingdom (liberal regime), Greece and Spain (sub-protective regime), and Bulgaria, the Czech Republic and Poland (transitional/post-socialist regime).

The chapter is based on quantitative and qualitative information: various databases (Eurostat, OECD, Eurofound and national statistics) have been employed, as well as the national reports drawn up under the NEGOTIATE project, diverse national sources from ministries, and journal articles on policy development in the above nine European countries. 


\section{POLICY ADAPTATIONS IN FOUR POLICY FIELDS}

\subsection{Education and Training}

In this section we analyse the basic aspects of education policies influencing the profile and scope of education, as well as policy efforts regarding school-to-work transitions. Following the theoretical discussion in Hora et al. (Chapter 7 this volume), we use the dimension of vocational specificity as the key criterion by which education systems differ. We analyse this dimension in these terms:

1. Share of students in upper-secondary education (indicator of the vocational education enrolment rate at the ISCED 3 level);

2. 'Intensity of vocationality' in vocational education - the form/type/ place of vocational education and training programmes preferred; see Eichhorst et al. (2015) and Dingeldey et al. (2017);

3. Link between education and the labour market (expressed not only in the form of training but also in employer involvement in defining education quality standards regarding curricula and/or school-leaving qualifications).

The latter indicator is closely related to the dimension of standardization of educational provisions, emphasizing the quality of such provisions, amongst other factors. The quality of educational measures also depends to a certain degree on the financial capacities of education systems (Hora et al., 2016). Both of these questions (quality of educational provision and funding) are also marginally discussed. We try to assess how different regimes of education policy address transitions from education to the labour market with the aim of preventing early job insecurity. We also analyse changes in the key provisions of education policies in times of economic recession.

Norway, as the only representative of the inclusive/universal regime, considers education, research and innovation to be top priorities. Accordingly, the quality of education and its funding are widely discussed and publicly supported. The education system is characterized by non-differentiated schooling until the age of 16 , with an emphasis on a relatively balanced structure of post-secondary education programmes and widely accessible higher (tertiary) education. Some scholars tend to describe the current education system in Norway as fairly dual (Bol and Van de Werfhorst, 2013; Quintini et al., 2007). The role of vocational streams in post-secondary education has been systematically strengthened since the beginning of the 
1990s; Reform 94 expanded the opportunities for young people to enter high-quality vocational education and training (Schoyen and Vedeler, 2016). Throughout this framework, the role of employers in the process of specifying and delivering training is expanding, and school-to-work transitions are rapid and smooth. Formally, Norway highly values the concept of free choice between educational paths, as do other representatives of the universal regime. However, in reality the dual system forces young people to consider and carefully choose the 'right' path. Subsequent changes are possible but sometimes not easy, given the poor throughput of students from upper-secondary education (Schoyen and Vedeler, 2016). Moreover, the key challenge faced by the Norwegian education system is a high and steadily growing rate of dropout or failure in upper-secondary vocational education, which seems to be caused by a lack of basic skills in students completing primary education. As this problem intensified during the economic recession, in the period 2010-13 Norway introduced a 'followup service' addressing young dropouts (16-21 years old); the aim was to motivate them to gain educational or vocational training, or alternatively to get a job (Schoyen and Vedeler, 2016).

The employment-centred countries (Germany and Switzerland) are characterized by moderate total expenditure on education (close to 5 per cent of GDP) and a strong emphasis on vocational education. In Switzerland the percentage of students who participated in vocational programmes at the upper-secondary level exceeded 60 per cent in the last seven years, while in Germany the proportion of students in vocational education compared to general education is more balanced. In both countries the traditional dual vocational training system really exists, with a high degree of formalization and strong involvement of the social partners. The training provided leads to a centrally accredited occupational qualification. Training institutions cooperate closely with advisory board representatives on developing and maintaining curricula (Eichhorst et al., 2015). The level of standardization of educational provision (educational output) is high in Germany and relatively lower in Switzerland (Bol and Van de Werfhorst, 2013). Because of the rather small impact of the economic recession on the situation of young people in these countries, the measures that were adopted continued to focus on how to simplify entry into the labour market for young people. In Switzerland there was provision of career counselling and guidance (vocational education case management), as well as the introduction of pre-vocational years (the expansion of 'interim solutions', Imdorf et al., 2016). In Germany the decreasing number of training companies led to reduced access to apprenticeship positions for young people (especially those at risk). This caused a revision of the 'transition system' so as to make it possible to intervene during 
secondary education (e.g., through a programme of 'education chains' or the intensification of career counselling for young people; Dingeldey and Steinberg, 2016). In both countries the freedom to choose between educational paths, especially between tertiary and vocational education, has been a topic of recent debates and has generated an increase in upward and downward inter-programme mobility, leading to better labour market matches (Eichhorst et al., 2015).

The liberal regime of youth transition is represented by the United Kingdom, where the emphasis on education is also relatively high, with expenditure reaching the level common in countries with an inclusivel universal model. The school system in the United Kingdom is broadly comprehensive until the age of 16 , with a clear academic track but a less clear-cut vocational track after the age of 16 (West and Nikolai, 2013). General (transferable) skills are emphasized not only in the academic but also in the vocational education pathway, with only weak links to the needs of employers (Bussi and O'Reilly, 2016), which makes school-to-work transitions more complicated, protracted and insecure. On the other hand, the more flexible education structure enables greater mobility of students between education tracks. In addition, mobility in education programmes as well as in occupations has been supported through the more general/ transferable nature of knowledge, which is important especially in times of economic recession. In order to strengthen the link between education and the labour market, the Apprenticeship Trailblazers programme and the Apprenticeship Grant for Employers were launched in 2012, with the subsequent introduction of the Apprenticeship Levy to encourage employers to open up more training positions for young people (Bussi and O'Reilly, 2016); however, recent evidence suggests that there has been a very poor take-up of this policy (CIPD, 2018). During the crisis, the British government also emphasized measures to decrease the proportion of dropouts as well as the share of 18-year-olds not in employment, education or training (NEETs). Important reforms have gradually raised the school-leaving age to 18 years, imposed a legal obligation for schools to provide students with access to independent career services/counselling and expanded the establishment of 'Academies' to replace poor-performance schools (Bussi and O'Reilly, 2016).

In countries in the sub-protective regime (Spain and Greece), education is not seen as a priority of public policy. This is reflected in the relatively low public spending on education and the inadequate quality of opportunities for training and lifelong learning (Hadjivassiliou et al., 2016). In these countries a school-based vocational education system clearly dominates. In reality, dual tracks do not exist and work-based or firm-specific training play only a minor to marginal role (Dingeldey et al., 
2017). Education systems are rather stratified and centrally standardized, especially at the level of educational inputs such as curricula (see Bol and Van de Werfhorst, 2013; Eichhorst et al., 2015). The freedom to choose educational pathways is formally declared. In Spain, for instance, this is strengthened by broad access to tertiary education, which simultaneously escalates the problem of overqualification (Ayllón and Ferreira-Batista, 2016). Due to these aspects, school-to-work transitions are protracted and difficult (even for qualified youth). Moreover, both countries have been having difficulty achieving higher-quality education for a long time. During the period of economic recession, this challenge resulted in a set of measures increasing the quality of both tertiary and vocational education. On the tertiary level, this includes the implementation of credit units and the restructuring of the university administration system in Greece (Karamessini et al., 2016). Both countries have also promoted vocational streams in upper-secondary education. Spain proposed the creation of some optional vocational pathways and a new vocational education and training diploma for mid-level training, as well as financial incentives for greater involvement of enterprises in the process of vocational education (Ayllón and Ferreira-Batista, 2016). Greece replaced vocational training schools with a more comprehensive system providing vocational apprenticeships in cooperation with the Greek public employment service (PES; Karamessini et al., 2016).

The education systems in countries characterized by the transitional/ post-socialist regime (Poland, the Czech Republic and Bulgaria) are considered to be rather underfunded; however, the situation is slowly improving in some respects. Compulsory education systems are comprehensive and relatively highly standardized (Hadjivassiliou et al., 2016). Although the structure of post-secondary education programmes varies according to the specificities of each country, one feature is still common to all of them: only very few places follow a real dual track, although vocational education programmes that include work-based or firm-specific training are quite frequent (involving 10 per cent to 50 per cent of all students in vocational education; Dingeldey et al., 2017). In all three countries the question of the quality of vocational education - as well as the high degree of stratification of educational opportunity - is widely discussed. Particularly in the Czech Republic the principle of early tracking (at 11 years) forecloses more academic paths of education for many young people at an early stage (Atzmüller, 2012). As a result, freedom of choice is in reality often restricted in these countries, and transitions from education to the labour market tend to be more difficult and insecure. Another complicated situation for youth is linked to the long-standing weaknesses of the education systems, such as the low quality of (vocational) education, underfunding, 
less effective allocation of public funds and weak linkage of education to the needs of employers, thus resulting in low employability of graduates.

Some partial changes in the education systems were made during the recession to address these problems. Poland focused more intensively on the quality of vocational education (see Michon and Buttler, 2016), while Bulgaria and the Czech Republic concentrated on how to increase the economic efficiency of funding in education, with an emphasis on performance indicators rather than simple inputs (Stoilova et al., 2016). In all three countries there has been an evident effort to strengthen the role of employers in defining standards of education as well as requirements regarding the final competences of graduates.

\subsection{Active Labour Market Policies and Activation}

Below we assess developments in active labour market policy (ALMP) measures with a focus on young people during the crisis. Policy effort is primarily indicated by total ALMP expenditure standardized per 1 per cent of general unemployment. Total ALMP expenditure includes: PES and administration (including placement and related services), training, employment incentives, supported employment and rehabilitation, direct job creation and start-up incentives (as identified in the OECD database on labour market policy). We also provide data on training as a complementary measure because this category is especially indicative of the human-capital development/enabling approach (HCD/EA). Data on ALMP expenditure for the young are not available. Similarly, although the Eurostat database provides data on ALMP measures for participants in the age category under 25 years, there are large gaps in the data, which is why we do not use them here. We do not establish any clear cut-off points for the expenditure figures; instead, we refer to the differences across the countries and policy regimes. Furthermore, qualitative information on changes in policies in the individual countries is provided, based on the national reports of the NEGOTIATE project.

Norway represents the inclusive labour market regime. Unemployment of young people is quite low there and not much affected by the crisis, and ALMPs are well developed. The level of ALMP expenditure per 1 per cent of unemployment is relatively high in Norway ( 0.147 per cent of GDP in 2013). Similarly, expenditure on labour market training per 1 per cent of unemployment stock is high (0.082 per cent of GDP in 2013), representing a considerable share of ALMP expenditure (see Table 8.1). These figures suggest that Norway follows a HCD approach (see Hora et al., Chapter 7 this volume).

Significant reforms of labour market policies were undertaken in 
Table 8.1 Expenditure on ALMP measures as a percentage of GDP and expenditure on labour market training - all standardized per 1 per cent of the unemployment rate (unemployment rates by labour force survey in parentheses)

\begin{tabular}{llll}
\hline & \multicolumn{1}{c}{2007} & \multicolumn{1}{c}{2010} & \multicolumn{1}{c}{2013} \\
\hline Norway & $0.216(2.5)$ & $0.177(3.5)$ & $0.147(3.4)$ \\
& 0.144 & 0.109 & 0.082 \\
Germany & $0.096(8.7)$ & $0.141(7.1)$ & $0.129(5.2)$ \\
& 0.037 & 0.042 & 0.051 \\
Switzerland &.. & $0.133(4.5)$ & $0.127(4.4)$ \\
& & 0.091 & 0.089 \\
United Kingdom & $0.06(5.3)$ & $0.05(7.8)$ & $0.03(8.0)-2011$ \\
Spain & 0.004 & 0.005 & 0.001 \\
& $0.09(8.2)$ & $0.05(19.9)$ & $0.025(24.8)-2012$ \\
Greece & 0.025 & 0.014 & 0.001 \\
& $0.02(8.4)$ & $0.02(12.7)$ &..$(27.5)$ \\
Poland & 0.006 & 0.002 & \\
Czech Republic & $0.05(9.6)$ & $0.07(9.6)$ & $0.04(10.1)$ \\
& 0.029 & 0.026 & 0.025 \\
Bulgaria & $0.05(5.3)$ & $0.04(7.3)$ & $0.05(7.0)$ \\
& 0.013 & 0.016 & 0.016 \\
& $0.03(6.9)$ & $0.02(10.3)$ & $0.015(13.0)$ \\
& 0.002 & 0.001 & 0.001 \\
\hline
\end{tabular}

Notes: Total ALMP expenditure (including PES and administration) on the first line; expenditure on labour market training on the second line in italics.

Source: OECD labour market database, authors' computations.

Norway prior to the crisis. The Youth Guarantee had been implemented since 1979 for the 16-19 age group and since 1995 for youth aged below 25. In 2005 public-sector reforms merged employment services, social insurance administration and municipal social services into 'one-stop shops'. Some local welfare and employment offices also have their own youth teams (Schoyen and Vedeler 2016). During the crisis there was an effort to fine-tune the instruments of governance of policies for young people: the Job Strategy of 2012 brought measures for the group aged under 30 with disabilities; in 2014, the Inclusive Working Life Agreement, covering more than half of all employees, was renewed by the social partners (Schoyen and Vedeler, 2016).

In the countries of the employment-centred regime (Germany and Switzerland), a HCD approach is also indicated by the level of ALMP 
expenditure per 1 per cent of unemployment stock. Recently it has been high - about 0.13 per cent of GDP. Similarly, expenditure on labour market training per 1 per cent of unemployment stock was considerable: 0.089 per cent of GDP in Switzerland and 0.051 per cent of GDP in Germany in 2013. Nevertheless, during the crisis, work-first measures were expanded in both countries. The introduction of more severe sanctions reduced access to benefits for young people and led to a stronger emphasis on moral obligations and individual responsibility. In Germany even before the crisis, the Hartz reforms in 2000-05 changed the profile of ALMP towards more support for job search (casework) and introduced stricter sanctions for people aged under 25 in cases where obligations of the Individual Action Plan were not met. The year 2011 saw the passing of the Act to Improve Chances for Integration, which accentuated improved job-matching. The implementation plan of the Youth Guarantee of 2014 emphasized a more needs-based approach, training youth at risk in particular; it also aimed at measures focusing on the integration of services in the form of a Job Agency for Youth (municipality and employment services merger) (Dingeldey and Steinberg, 2016). In Switzerland internship positions were doubled in 2010 in order to counteract the reduced job opportunities in the labour market during the economic crisis. On the other hand, the reforms of unemployment insurance brought a shorter maximum benefit duration for some groups of unemployed: persons who had made no previous contributions received four months of benefits instead of 12, and a waiting period of 120 days was enacted for youth who had quit school (see Imdorf et al., 2016).

In the United Kingdom, representing the liberal employment regime, ALMP expenditure per 1 per cent of unemployment amounted to 0.06 per cent in 2007 and dropped to 0.03 per cent of GDP in 2011 (data for 2013 are not available); expenditure on labour market training per 1 per cent of unemployment was 0.004 per cent of GDP in 2007 but had dropped significantly to 0.001 per cent of GDP by 2011. The United Kingdom is unique in its emphasis on supporting job search (job mediation and counselling). Data show that between 0.2 per cent and 0.3 per cent of GDP (during the 2009-10 crisis years) was provided for PES administration, including placement and related services. The new measures implemented during the crisis consistently went in the work-first direction: from 2010-11 the Young Person's Guarantee of a job offer, training or job experience was applied after six months. This was supported by the Community Task Force programme, Routes into Work: Pre-employment Training, and Work-Focused Training. In 2012 the broader initiative 'Making Work Pay' welfare reform brought Claimant Commitments (individual action contracts), which were accompanied by stricter sanctions, as well as 
Youth Contracts, in particular, which were accompanied by new support programmes. Finally, a 12-month programme for hard-to-place NEETs was established, which included 'work coaches' and ad hoc teams for youth, training measures, work experience for two to eight months, and coverage of the costs of travel and childcare for newly employed young people (Bussi and O'Reilly, 2016).

The countries of the sub-protective employment regime (Spain and Greece) experienced a harsh economic recession and a considerable increase in general unemployment rates, especially youth unemployment (see Karamessini et al., Chapter 2 this volume). ALMP expenditure per 1 per cent of unemployment fell: in Spain from 0.09 per cent of GDP in 2007 (which was comparable with Germany) to 0.05 per cent of GDP in 2010 and to 0.025 per cent of GDP in 2012. In Greece expenditure on ALMP remained stable at around 0.02 per cent of GDP in 2007 and 2010 (data for 2013 are not available). The crisis and high levels of youth unemployment forced countries to adopt some reforms aimed at activation ('commitment to activity'), mainly regarding recipients of social assistance. New instruments were used that targeted the most affected groups and the young unemployed, in particular; they seem, however, to be low-cost measures (Ayllón and Ferreira-Batista, 2016). In Greece a new generation of active measures followed from 2010: new employment promotion and workexperience measures covered about 12 per cent of the unemployment stock. Work schemes in public works and training measures have been supported since 2012, and training vouchers were implemented in 2013; these measures were, however, criticized because of poor management, with 75 per cent of subsidies going to training companies instead of the unemployed. This was reversed by the new government, elected in 2014, which decided that 80 per cent of subsidies should flow to the unemployed (Karamessini et al., 2016).

In countries with a transitional/post-socialist employment regime, ALMP expenditure per 1 per cent of unemployment is low, although it is somewhat higher in the Czech Republic ( 0.05 per cent) and Poland ( 0.04 per cent) than in Bulgaria (0.015 per cent of GDP in 2013). Expenditure on labour market training per 1 per cent of unemployment was again rather low, although somewhat higher in Poland ( 0.025 per cent of GDP) than in the Czech Republic ( 0.016 per cent of GDP), and only 0.001 per cent of GDP in Bulgaria.

In Poland the crisis brought more changes in policies (especially for young people) than in the Czech Republic; these changes came in the form of new and more targeted programmes, in spite of their decreasing scope. In 2012 the Youth in the Labour Market programme introduced some new tools; for instance, some special programmes for marginalized youth were 
implemented through 600 administrative units (Voluntary Labour Corps) in the country. The 2014 Act on Youth Guarantee continued to enrich the variety of ALMP instruments, including Individual Action Plans for young unemployed people after a two-month period of unemployment. The National Economic Bank introduced a preferential loan scheme for youth entrepreneurship, which was implemented in 2015 (Michoń and Buttler, 2016).

In the Czech Republic the main strategy was the protection of existing jobs through measures financed from the European Social Fund, such as in-work education combined with reduced working time. On the other hand, the government cut the scope of ALMP measures during 2010-12 as well as the numbers of PES staff, while implementing governance reforms (centralization and merging of employment services with social assistance). In 2013 a corrective turn was observed in the increase of the scope of ALMP measures, including apprenticeships for young people (Hora et al., 2016).

In Bulgaria the Amendment of Employment Strategy came rather late (2013). This new instrument was aimed at making the young labour force more flexible: school graduates (including tertiary level) under 25 obtained subsidized temporary job opportunities for a period of 6-12 months, during which they were remunerated at the level of the minimum wage and had support from a tutor. At the same time, flexible contracts consisting of working-time accounts were introduced to the Labour Code. Subsequently, Individual Action Plans for Youth were implemented. Furthermore, the minimum wage was considerably increased (doubled) in 2015 so as to counterbalance the above-mentioned flexibilization measures (Stoilova et al., 2016).

\subsection{Employment Protection}

Systems of employment protection (EPL) are assessed mainly according to the following criteria: (1) total level of employment protection for individuals with (1a) a temporary contract or (1b) permanent contract; or (1c) against collective dismissals; (2) specific criteria: (2a) restrictions on other than standard (unlimited) contracts: general permission/use only for objective reasons, maximum length of temporary contracts and maximum number of allowed renewals, (2b) protection during termination of contracts: notice period and severance pay, (2c) wage protection: minimum wage or specific minimum wage. See Tables 8A.1 and 8A.2 in the Appendix, this chapter.

When assessing the level of EPL indexes, the countries represent the specific employment regime types well - in correspondence with the 
assumptions made by Muffels et al. (2014). Some crucial changes in employment protection were made in many countries long before the period in focus; however, recent reforms in Greece, Spain and the Czech Republic are worthy of attention.

The inclusive regime (Norway) is characterized by high EPL for temporary workers and low protection against collective dismissal (flexicurity regime). The share of temporary employment amongst young people is not high compared to other countries, although it is much higher when compared to older cohorts. Although temporary contracts were generally allowed in 2015, there are important limitations that effectively reduce their overuse. Wages at sectoral or firm level are set by collective agreements (Schoyen and Vedeler, 2016).

The employment-centred/dualistic regime is characterized by high protection against collective dismissals and stronger protection of regular workers (Germany), but weaker protection of temporary workers. The EPL system in Switzerland seems to be generally less protective than the system in Germany. EPL in Germany is based on previous work record, and young workers are often less protected (Dingeldey and Steinberg, 2016). Those with temporary contracts have weak protection (even lower for the previously unemployed), and the share of temporary contracts for young people is very high (flexibilization of the margins). Work of an occasional or limited nature is realized in 'mini-jobs'. There have been some recent efforts to improve conditions for temporary and/or low-intensity workers. The minimum wage was introduced in 2015 (although it is not applicable to people aged under 18 years, apprentices or the long-term unemployed).

Switzerland has a rather low level of employment protection. The length of the trial period is the shortest of all the assessed countries. The notice period for dismissal is shorter for those with temporary contracts. The share of young people working on temporary contracts is very high, although the data for the youngest cohorts could be influenced by the existence of apprenticeship and ALMP programmes (see Imdorf et al., 2016). There are special regulations aimed at preventing the completion of serial short-term employment contracts (Imdorf et al., 2016). Zero-hours contracts are allowed. Minimum wages at sectoral or firm level are set by collective agreements (Imdorf et al., 2016).

The liberal regime provides very low levels of protection in all three categories (regular, temporary individual contracts, collective dismissals). In the United Kingdom the trial period is based on an agreement between the employer and employee. The low level of temporary employment is explained by the low EPL for regular contracts. A relatively high share of young people in the United Kingdom have also worked on these contracts voluntarily (Bussi and O'Reilly, 2016). Zero-hours contracts are allowed 
and often used by young people. Young people have been excluded from the National Living Wage, introduced in 2016, and their minimum wage is lower than that of older cohorts.

The sub-protective regime is characterized by dualism, a relatively high level of protection of temporary contracts and a high level of protection against collective dismissals. Reforms of the negotiating process with the aim of reducing trade union power and relaxing the rules for collective dismissals were an important part of the EPL changes (Ayllón and Ferreira-Batista, 2016; Karamessini et al., 2016). Reforms implemented in Spain (in 2010 and 2012) were targeted at the enhancement of permanent employment. Overall, there is some reduction of protection in permanent employment (prolongation of trial period to 12 months, reduction of severance pay), which is accompanied by a slight increase in protection of temporary contracts. Reforms so far have not been sufficient to deal with the structural duality of the Spanish labour market (Ayllón and Ferreira-Batista, 2016). The situation in Greece was heavily influenced by the Economic Adjustment Programme (EAP). Reforms made the labour market more flexible in 2010 and 2011, allowing the unlimited renewal of temporary employment contracts with objective reason, the reduction of the notice period and severance pay, an automatic trial period of 12 months and easier use of agency work. The right to set minimum wages was removed from employers and trade unions and transferred to the state. There is a specific minimum wage for young people set at a lower level. In accordance with EAP goals, the minimum wage was decreased by 22 per cent (Karamessini et al., 2016).

The transitional/post-socialist regime provides a low level of protection against collective dismissals, but better protection of regular than of temporary contracts. While the institutional characteristics of EPL in these countries are quite similar at first glance, the results are sometimes very different. Late reforms in all three countries were aimed at significant increases in minimum wages. Poland is typical for having a very high share of temporary contracts for both older people and young people (three out of four). These contracts entail worse employment conditions but are not as unstable as expected (Michoń and Buttler, 2016). Civil law contracts (i.e., contracts based on the civil code - see Eurofound, 2002) may be overused (Michoń and Buttler, 2016). Recent reforms have sought to improve conditions for temporary and/or low-intensity workers and to improve wage conditions. There is a national minimum monthly (but not hourly) wage. A special lower minimum wage is set for people working for their first year. In the Czech Republic employment protection for young people was substantially reduced by a reform implemented in 2012. It reduced severance pay for shorter contracts, prolonged the maximum period of 
temporary contracts and raised the ceiling of hours in Agreements for a Specific Task. Exceptionally, three successive temporary contracts can be held over a nine-year period. The special minimum wage for the young or apprentices was cancelled in 2013 (Hora et al., 2016).

In Bulgaria the level of employment protection is relatively high for short-term contracts, but lower for longer contracts (there is a long trial period, a one-month notice period and no severance pay). The share of temporary contracts is very low for young people and its recent increase is probably influenced by the participation of young people in subsidized jobs (Stoilova et al., 2016). There are new specific contracts for working on particular days of the month and new agricultural contracts (see Keller and Darby, 2013; Stoilova et al., 2016).

Overall, most of the EPL conditions for young people in the above countries show only minimum individual employment protection. Young people are over-represented in flexible employment and low-paid workplaces. However, one of the key differences across the countries is in the proportion and composition of young people who are subject to weak EPL. In some countries both low-qualified and high-qualified young people are highly affected (Spain, Switzerland), while in other countries (Germany) there is a great difference between the low and the highly educated. At the same time, the situation of university graduates may be different when Spain is compared with Switzerland (see Ayllón and Ferreira-Batista, 2016; Imdorf et al., 2016).

\subsection{Unemployment Protection}

In this section we use the following assessment criteria:

1. Logic of unemployment protection: (1a) existence of a system providing protection to young people, (1b) universalistic/fragmented or decentralized character of the system;

2. Eligibility criteria and their outcomes: (2a) rules for entitlement to unemployment insurance benefits, (2b) benefit coverage - provides information about the share of the unemployed (general and young people) who receive benefits at a given time;

3. Generosity of protection: replacement rates provided by OECD in (3a) initial and (3b) long-term periods.

See Table 8A.3 in the Appendix, this chapter. For this assessment we suppose that people are aged up to 30 years old and that a qualification period of 5 years or more was not acquired.

Norway (inclusive regime) provides generous protection for a longer 
period of time. Nevertheless, young people may have problems qualifying because of a limited record of past income: people with low incomes obtain half the benefit duration (Schoyen and Vedeler, 2016). On the other hand, work-integration benefits (employment scheme benefit, qualification programme) can be provided to young people. Norway has the lowest unemployment benefit coverage (30.6 per cent) amongst the Northern European countries (Gallie, 2013). Using different data, Lorentzen et al. (2014) show that unemployment benefit coverage in Norway was usually higher than 30 per cent when looking at longer periods. For young people (under 25 years), it was about 30-45 per cent in the period 2005-10. More generally, Gallie (2013) suggests that the unemployment protection systems in Northern Europe might be moving in the direction of the employment-centred regime.

The employment-centred (dualistic) regime provides protection for a longer period of time, good coverage (Germany) and a generous amount (Switzerland). However, young people are not equally involved in the unemployment insurance system and their protection is dependent on eligibility within the social assistance system. Entitlement to the system of unemployment insurance in Germany is strongly based on previous contributions. Overall, there is high coverage of unemployment benefits for young people (84.4 per cent). About one-third (32.6 per cent) receive unemployment insurance. The others draw flat-rate, means-tested benefits (55.7 per cent) or are dependent on their parents (Dingeldey and Steinberg, 2016). Unemployment assistance generosity is based on age and family situation criteria (which results in lower benefits for young people). In Switzerland there is special protection within unemployment insurance for people making the transition from education to work, but with a waiting period of an additional 120 days (Imdorf et al., 2016). The 2011 reform linked benefits more closely to the period of contribution. Benefits are at a flat rate (categorically defined) for people who cannot prove their previous earnings. Young people without support obligations are entitled to a shorter duration of benefits. Before these reforms, the coverage of unemployment benefits for young people (up to 25 years) was about 30 per cent (Chabanet and Giugni, 2013).

The liberal regime (United Kingdom) provides the least generous protection, even in the initial period; however, the duration and coverage are better (considering social assistance) than in the sub-protective or transitional/post-socialist regimes. Unemployment insurance benefits are provided at a flat rate and the duration of benefits is short. Several benefits have recently been replaced by a new form of social assistance (Universal Credit). Many young people are not entitled to either a Jobseeker's Allowance or the Universal Credit (Bussi and O'Reilly, 2016). 
The sub-protective regime provides poor benefit coverage, especially for the young, since the family is expected to provide protection. The system is somewhat fragmented: there are many schemes with rather limited duration and residual or non-existent support for young people. In Spain strict conditionality applies to unemployment insurance (including benefit duration). Young people are by their age explicitly excluded from unemployment assistance programmes and have access only to marginal, means-tested programmes. The one-time work-integration benefit (PRODI/PREPARA) has been in effect since 2009. The system in Greece is described as residual, fragmented and with low ability to reduce poverty (Karamessini et al., 2016). Unemployment insurance has rather strict entitlement conditions and the coverage is very low. There is the additional requirement of 80 days of contributions for first-time claimants. The benefit level was substantially reduced with reforms to the minimum wage in 2012. There is a special (new labour market entrant) allowance for long-term unemployed young people; however, it is low and is granted for only five months. Social assistance was introduced as a pilot scheme in 2014.

The transitionallpost-socialist regime provides poor coverage, especially for young people, as well as a short duration of unemployment benefits and variable generosity (higher in the initial period, but very low in longterm unemployment). Low benefits are provided, despite the rather high benefit replacement rates set by law, due to the low previous work income of the unemployed (Hora et al., 2016; Stoilova et al., 2016).

In Poland social insurance benefits are related to basic income, local economic conditions and family situation. The benefit duration is rather short, but there is a system of social assistance that is conditional on unemployment. Most young people are not entitled to unemployment benefits: when they are, the coverage is extremely low, and the benefits are even lower for people who have worked for less than five years. People with low job intensity or low job incomes are not covered by unemployment benefits (Michoń and Buttler, 2016).

In the Czech Republic unemployment insurance benefits are related to previous earnings with decreasing benefit replacement rates and a flat rate for people who cannot prove their previous earnings (Hora et al., 2016). Access for young people to unemployment insurance and overall coverage is very low (studying is not counted as a period calculated towards entitlement).

In Bulgaria young people exiting the education system are excluded from unemployment benefits, which in any case have a very low level of coverage for young people. People with low job intensity are covered according to the pro-rata (in proportion) principle (Stoilova et al., 2016). 
A long waiting period (nine months) reduces the protection provided by social assistance (Stoilova et al., 2016).

To sum up, in one group of countries, we generally document very low unemployment protection for young people: Bulgaria, Poland, Greece, Spain, the Czech Republic and the United Kingdom. Conversely, in Switzerland, Norway and Germany, we can see much better income protection. Young people are often excluded from standard unemployment benefits (also see Maquet et al., 2016). In some countries they are covered by work-integration benefits (benefits for the disabled in specific cases). Sanctions during spells of unemployment are probably a substantial source of benefit exclusion in some countries (namely the United Kingdom and Germany).

The unemployment insurance programmes usually have relatively strict qualifying conditions depending not only on the previous work experience but also on the conditions of the former job contract. Older people (usually aged $50+$, with long-term contributions) are more protected, with longer and more generous benefits, while young people are not covered, or only at the basic level of protection. The other source of reduced income protection is explicit risk categorization in the form of age or family testing (for an explanation, see Hora et al., Chapter 7 this volume). These tests can lead to numerous situations: young people are excluded from benefits (in Spain), additional entitlement criteria are added to benefit entitlement formulas (in Switzerland), or the benefit generosity is based on age or family criteria (United Kingdom, Germany, Poland and Norway).

In terms of the generosity of the system measured by the OECD replacement rates in initial and long-term periods, we have divided the countries into groups by levels of protection: high and moderate (Switzerland), high and low (Bulgaria, Spain), moderate and moderate (Norway, Germany, the Czech Republic), moderate and low (Poland), low and moderate (the United Kingdom), and low and zero (Greece) - the new social assistance system was not yet counted there. The benefit coverage (see Table 8.2) can best explain the different levels of protection.

Germany provides benefits to a high proportion of (even the longterm) unemployed. The other countries for which at least some data are available (Bulgaria, Poland, the Czech Republic, the United Kingdom, Norway, Spain and Greece) provide moderate or low protection, usually less than half of the people are covered and there is a great difference between the coverage of the short-term and the long-term unemployed. This low coverage explains why some countries have a higher risk of poverty among the unemployed despite the high benefit replacement rates (Maquet et al., 2016). 


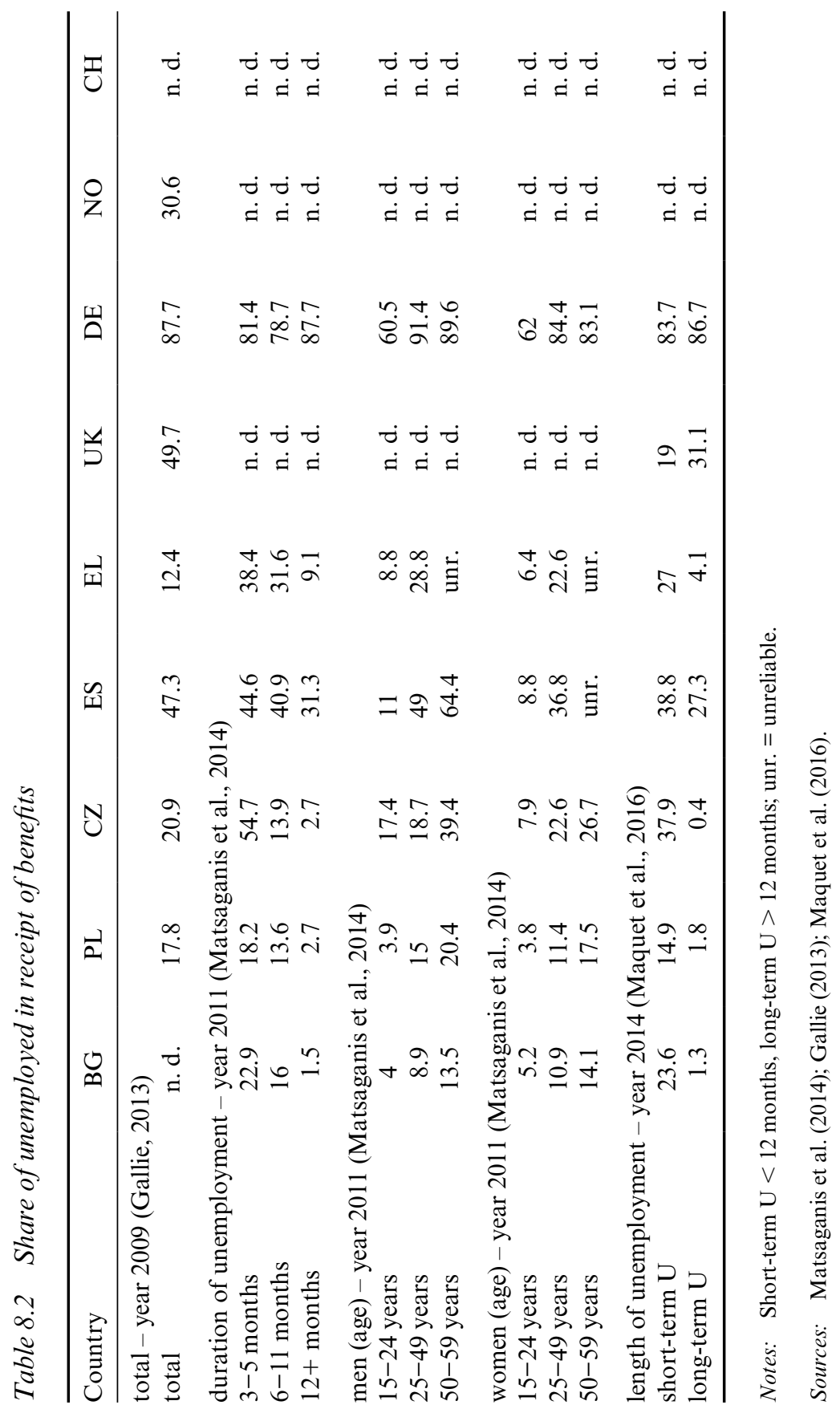




\section{CONCLUSIONS}

In this final discussion we summarize the findings regarding the questions in focus: How do the different countries respond to the challenges of early job insecurity? How appropriate were the responses to the problems the countries faced?

Long-term structural changes, such as changing demands for the hard and soft skills of the labour force, flexibilization and increasing dualism in the labour market, seem to have been important triggers for reforms, rather than the crisis alone. In many cases young people are amongst those making insecure transitions. Both as a consequence of restrictive changes in policies and the crisis itself, the position of youth has deteriorated in most countries.

Although education systems provide more young people with a higher level of education, this is not enough to prevent early employment insecurity. The general trend in nearly all of the countries studied was falling expenditure for ALMP measures. Second, a departure from training was observed in some countries, while in others there has already been a negligible emphasis on labour market/vocational training. Job creation/ occupation was more in focus as a prevailing trend, often in the form of protection of existing jobs and with more apprenticeship or internship positions for young people. Third, in most countries some governance reforms in ALMP and activation measures took place, aiming to make the policies more effective by integrating them and better targeting them to young people. Almost all the countries preferred less expensive measures; regarding the young unemployed, these were mainly job-search services, individual contracts, job experience and some training. The Youth Guarantee scheme did not substantially change the profile of the policies, but it did bring some financing opportunities.

Recent reforms in most countries slightly favoured (although differently) the work-first approach regarding the labour market entry of young people, although often through insecure, precarious (temporary) jobs. The data indicate that insecure jobs are hardly the best pathway in the sense of 'stepping stones' to stable jobs of good quality for most young unemployed; however, they might be considered as such for university-educated young people in some countries where unemployment is quite low (e.g., Switzerland). The human-capital development of young people was rather on the decline in ALMP (although it remains a high priority in countries like Norway, Germany and Switzerland); nevertheless, education systems showed some advancements elsewhere. In comparison to before the crisis, today's labour market policies, (un)employment protection and skills formation systems altogether provide less adequate protection from the 
risks of social exclusion entailed by job insecurity (and income insecurity) amongst young people.

The crisis served as a stimulus to the prevailing flexibilization trend; this was strongest in the countries of the sub-protective regime (Greece and Spain), leading to weaker job protection for the regular workforce (insiders). Parallel to this development, improvements for labour market entrants were only minor, leaving young people in a disadvantaged position regarding employment protection. Similarly, the reforms in income protection during unemployment brought some improvements for those with sufficient work records, while providing less security for those who lack them, young people included. This causes their increasing dependence on parents, particularly in countries of the sub-protective regime, where there are usually less developed social assistance schemes.

The crisis did not provoke an overhaul of the previous institutional mix. Instead only incremental changes occurred, classified by Hall (1993) mostly as 'first-order changes' (adjustments to existing instruments). Some new measures did appear in terms of the substance and governance of policies, and these may be considered 'second-order changes' (new instruments).

The distinctive features of the employment regimes as described in Hora et al. (Chapter 7 this volume) have become even more apparent in that the trend towards the work-first approach and flexibilization was stronger in liberal, sub-protective and transitional/post-socialist regime countries than in the inclusive and employment-centred countries. The policies in the specific employment regimes as they emerged during the crisis and beyond are characterized below (see Table 8.3).

The failures of the policy adaptations to address the issue of early job insecurity are most apparent in the countries in the sub-protective regime and also, to some extent, in the transitional/post-socialist regime. However, it is worth noting the magnitude of the problem and the deeply rooted dualism in the labour market in countries with these regimes (Spain, Greece, Bulgaria), all of which have been seriously affected by the crisis. Given the generally less developed policies, lower capacity of institutions and the limitations stemming from fiscal discipline measures, it is not realistic to expect any substantial advancements or effects of the policies because they are not sufficient to deal with the dimension and nature of the problem of early job insecurity. 


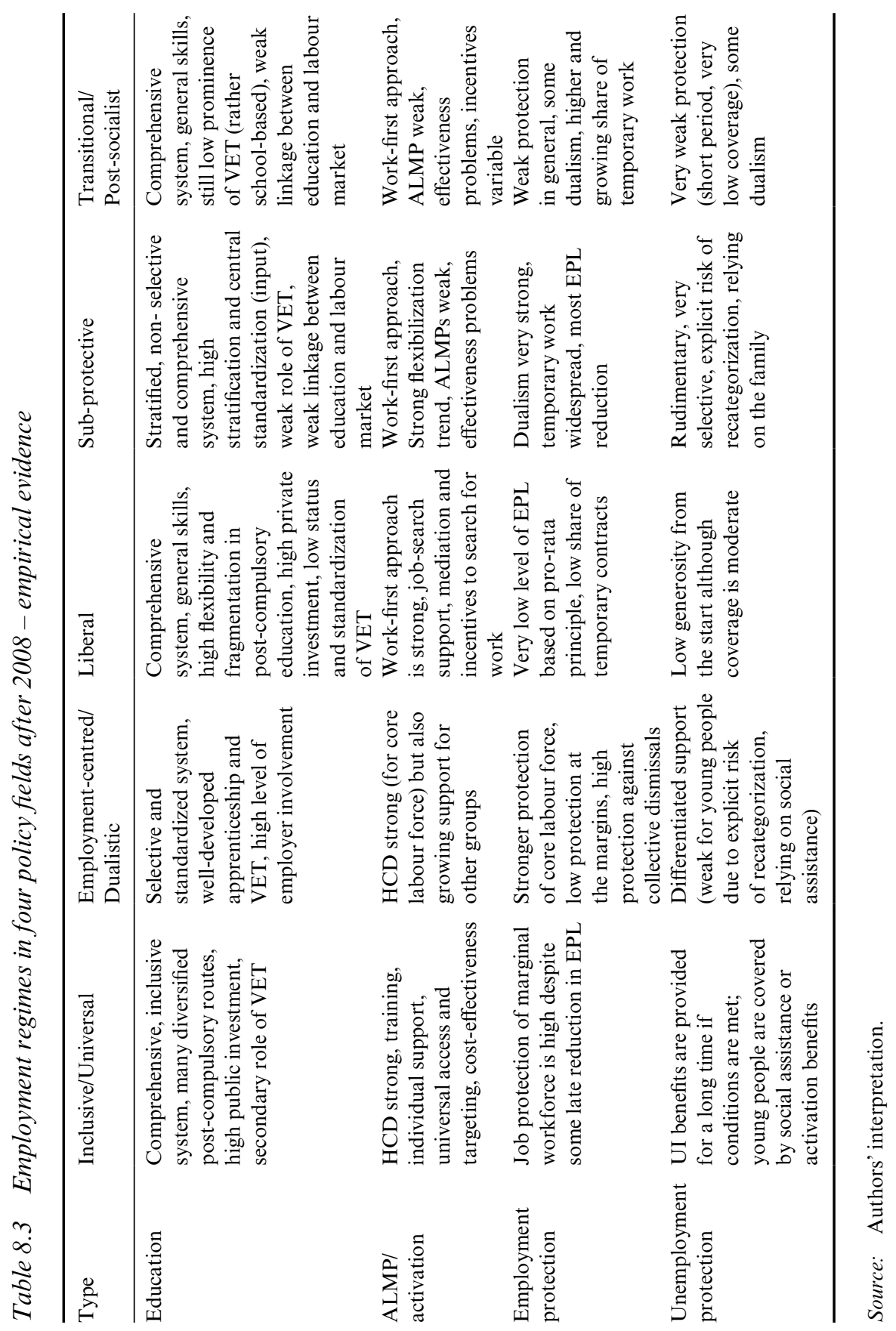




\section{REFERENCES}

Atzmüller R (2012) Dynamics of educational regimes and capability-oriented research. Social Work and Society 10(1): 1-15.

Ayllón S and Ferreira-Batista N (2016) Institutional determinants of early job insecurity in nine European countries. National Report Spain for NEGOTIATE Working Paper no. 3.4. https://negotiate-research.eu/files/2015/03/WP-3.4_Spain_ National-report.pdf (accessed 2 June 2018).

Bol T and Van de Werfhorst HG (2013) The measurement of tracking, vocational orientation, and standardization of educational systems: A comparative approach. AIAS, GINI Discussion Paper no. 81. Amsterdam: Institute for Advanced Labour Studies.

Bussi M and O'Reilly J (2016) Institutional determinants of early job insecurity in nine European countries. National Report United Kingdom for NEGOTIATE Working Paper no. 3.4. https://negotiate-research.eu/files/2015/04/WP3_4_Coun try_report_UK.pdf (accessed 2 June 2018).

Chabanet D and Giugni M (2013) Patterns of change in youth unemployment regimes: France and Switzerland compared. International Journal of Social Welfare 22(3): 310-18.

CIPD (2018) Assessing the early impact of the apprenticeship levy. London, UK: Chartered Institute of Personnel and Development. https://www.cipd.co.uk/Im ages/assessing-the-early-impact-of-the-apprenticeship-levy_2017-employers-pers pective_tcm18-36580.pdf (accessed 10 February 2018).

Dingeldey I, Assmann ML and Steinberg L (2017) Strategies to improve labour market integration of young people: Comparing policy coordination in nine European countries. NEGOTIATE Working Paper no. 8.2. https://negotiate-research.eu/ files/2015/04/NEGOTIATE_WP_8.2-_Strategies-to-improve-labour-market-inte gration-of-young-people.pdf (accessed 22 April 2018).

Dingeldey I and Steinberg L (2016) Institutional determinants of early job insecurity in nine European countries. National Report Germany for NEGOTIATE Working Paper no. 3.4. Unpublished document.

Eichhorst W, Rodríguez-Planas N, Schmidl R and Zimmermann KF (2015) A road map to vocational education and training in industrialized countries. Industrial Relations and Labour Review 68(2): 314-47.

Eurofound (2002) Forms of employment contract reviewed. https://www.eurofound. europa.eu/printpdf/observatories/eurwork/articles/forms-of-employment-contrac t-reviewed (accessed 1 February 2018).

Gallie D (2013) Economic crisis, the quality of work, and social integration: Issues and context. In: Gallie D (ed.) Economic Crisis, Quality of Work, and Social Integration. Oxford, UK: Oxford University Press, pp. 1-29.

Hadjivassiliou KP, Tassinari A, Eichhorst W and Wozny F (2016) Assessing the performance of school-to-work transition regimes in the EU. IZA Discussion Paper no. 10301. Bonn: Institute of Labor Economics.

Hall P (1993) Policy paradigms, social learning, and the state: The case of economic policymaking in Britain. Comparative Politics 25(3): 275-96.

Hora O, Horáková M and Sirovátka T (2016) Institutional determinants of early job insecurity in nine European countries. National Report Czech Republic for NEGOTIATE Working Paper no. 3.4. https://negotiate-research.eu/files/2015/03/ WP-3.4_CZ_National-report.pdf (accessed 5 May 2018). 
Imdorf C, Shi LP, Helbling L, Sacchi S and Samuel R (2016) Institutional determinants of early job insecurity in nine European countries. National Report Switzerland for NEGOTIATE Working Paper no. 3.4. https://negotiate-research. eu/files/2015/03/WP-3.4-Country-Report-Switzerland.pdf(accessed 5 May 2018).

Karamessini M, Kominou K and Papazachariou A (2016) Institutional determinants of early job insecurity in nine European countries. National Report Greece for NEGOTIATE Working Paper no. 3.4. See https://negotiate-research.eu/ files/2018/07/WP-3.4_National_Report-Greece.pdf (accessed 5 May 2018).

Keller L and Darby J (2013) International Labor and Employment Laws: Fourth Edition (Volume IIA). Bulgaria. Arlington: Bloomberg BNA.

Lorentzen T, Angelin A, Dahl E, Kauppinen T, Moisio P and Salonen T (2014) Unemployment and economic security for young adults in Finland, Norway and Sweden: From unemployment protection to poverty relief. International Journal of Social Welfare 23(1): 41-51.

Maquet I, Maestri V and Thévenot C (2016) The Coverage Rate of Income Support Measures in the EU: Measurement and Challenges. Luxembourg: Publications Office of the European Union.

Matsaganis M, Özdemir E and Ward T (2014) The Coverage Rate of Social Benefits. Social Situation Observatory Research Note no. 9. Brussels: European Commission.

Michoń P and Buttler D (2016) Institutional determinants of early job insecurity in nine European countries. National Report Poland for NEGOTIATE Working Paper no. 3.4. Unpublished document.

Muffels R, Crouch C and Wilthagen T (2014) Flexibility and security: National social models in transitional labour markets. Transfer: European Review of Labour and Research 20(1): 99-114.

Quintini G, Martin JP and Martin S (2007) The changing nature of the school-towork transition process in OECD countries. IZA Discussion Paper no. 2582. Bonn: Institute for the Study of Labor.

Schoyen MA and Vedeler J (2016) Institutional determinants of early job insecurity in nine European countries. National Report Norway for NEGOTIATE Working Paper no. 3.4. https://negotiate-research.eu/files/2015/03/WP-3.4_Country-reportNorway.pdf (accessed 5 May 2018).

Stoilova R, Boyadjieva P, Ilieva-Trichkova P, Krasteva V and Nyagolov L (2016) Institutional determinants of early job insecurity in nine European countries. National Report Bulgaria for NEGOTIATE Working Paper no. 3.4. See https:// negotiate-research.eu/files/2018/07/WP-3.4-National-Report-Bulgaria-ISSK. pdf (accessed 6 May 2018).

West A and Nikolai R (2013) Welfare regimes and education regimes: Equality of opportunity and expenditure in the EU (and US). Journal of Social Policy 42(3): 469-93. 


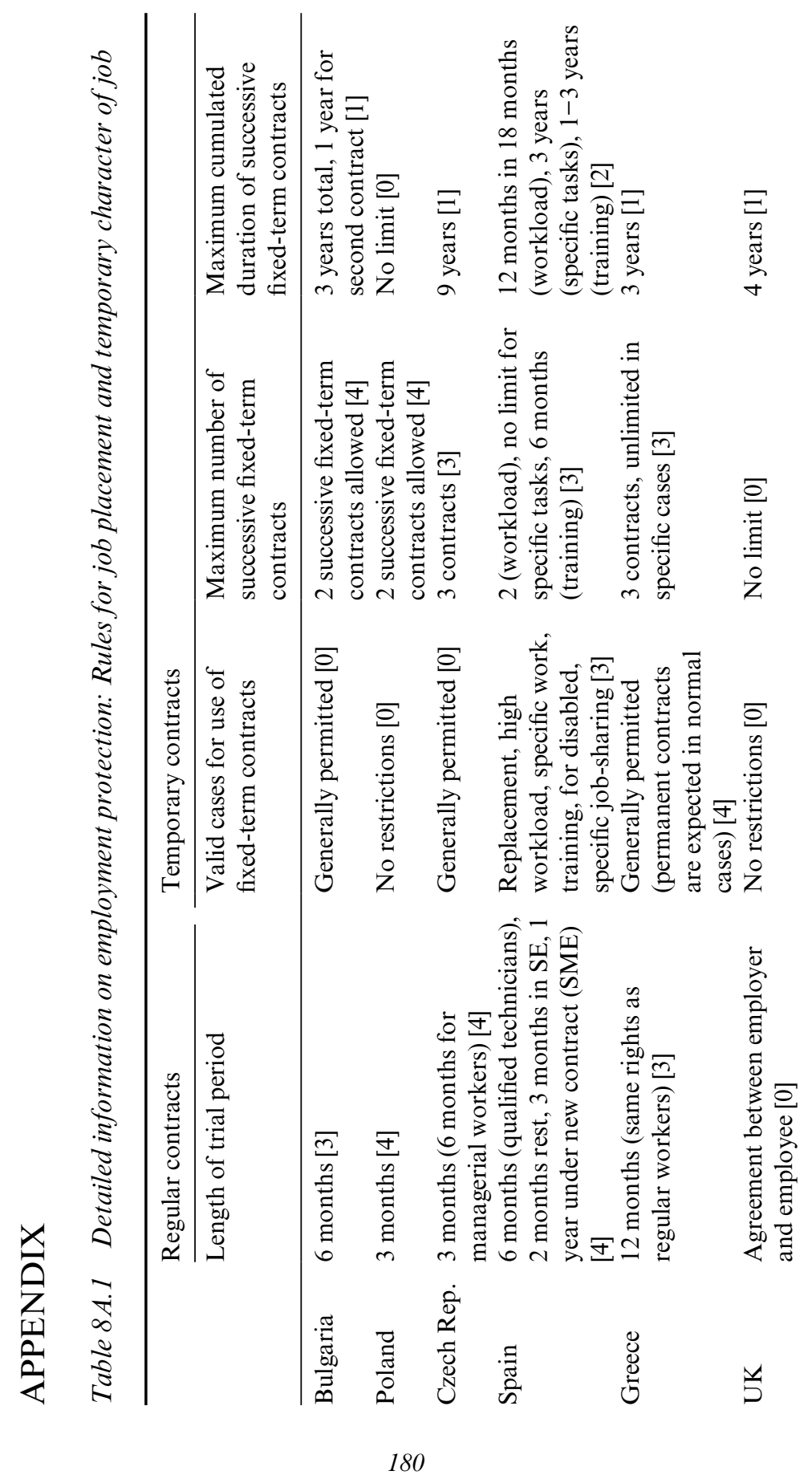




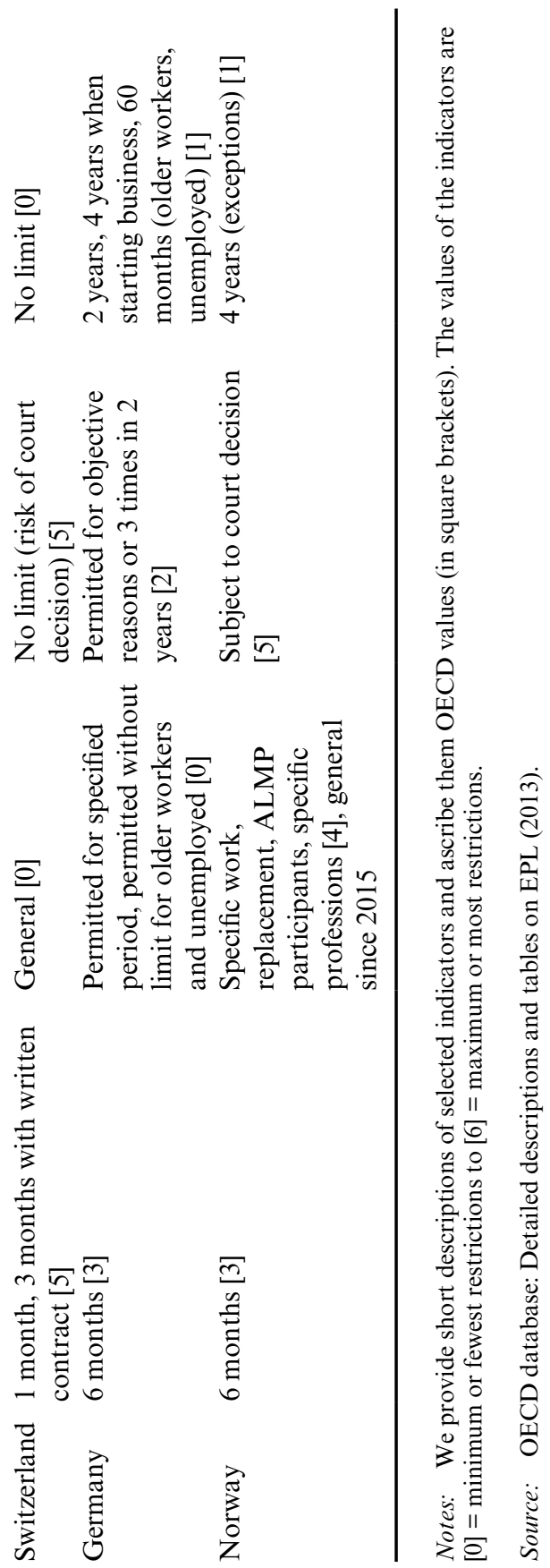

181 


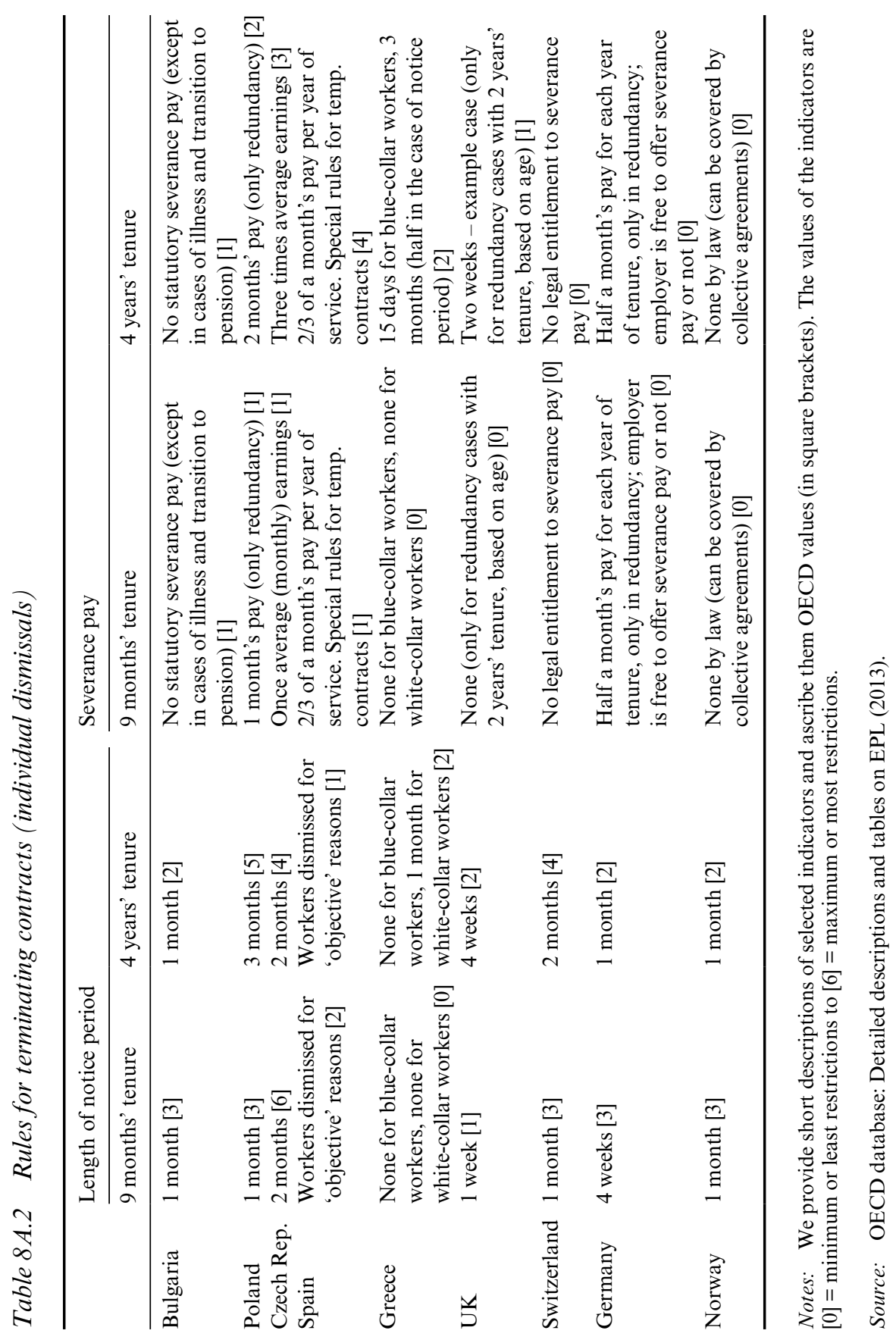




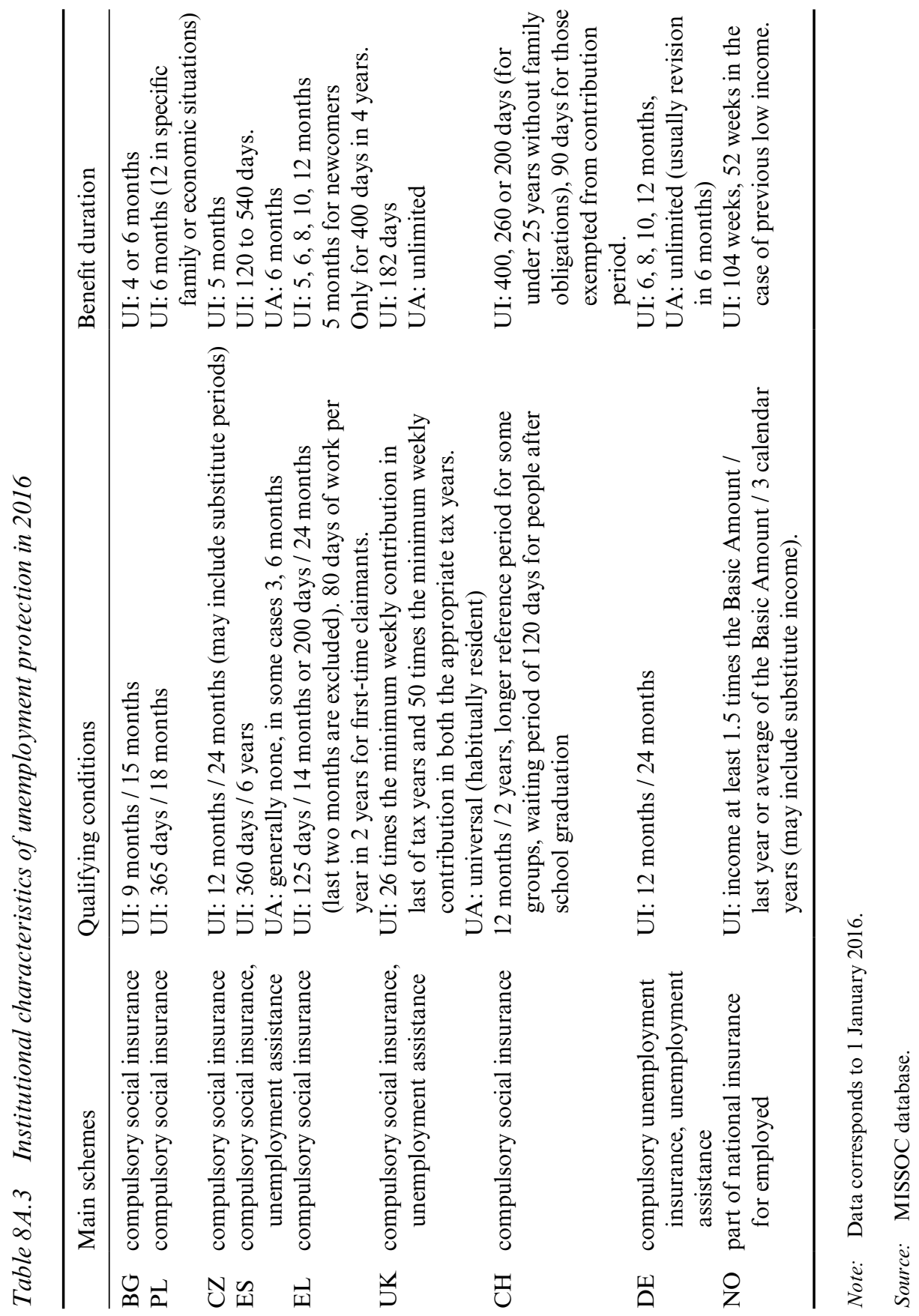

